\title{
Recent Advances in Systemic Scleroderma in Childhood
}

\author{
Zoltán Györgyi ${ }^{1}$, Ivan Foeldvari ${ }^{2}$, Peter Weiser ${ }^{3}$, András Szabó ${ }^{1}$, Tamás Constantin ${ }^{1}$
}

\begin{abstract}
Systemic sclerosis (SSc; scleroderma) is a systemic autoimmune disease characterised by diverse skin and internal organ involvement. The underlying pathology consists of fibrosis caused by fibroblast dysfunction and small vessel vasculopathy. It is much rarer in childhood, meaning 1 in 1 million children, approximately $3-10 \%$ of the adult incidence [1,2]. Only one tenth of juvenile scleroderma (jSSc) has disease onset before 16 years, patients under the age of 10 have equal distribution of males and females. Over 10 years of age, the female predominance as in adult patients, is evolving [3]. The currently published data suggest a dominance of the diffuse subset in children [3]. Pediatric patients have less pulmonary and gastroesophageal involvement and the CREST-syndrome is not observed in the pediatric population [3]. Pediatric patients have better survival rates compared to adults, the 5-year survival was found approximately 93-95\% [4,5]. In the following we attempt to review the hallmarks of this heterogenous disease concentrating on novelties, new results and recommendations.
\end{abstract}

Key words: Advances, systemic sclerosis

\section{Introduction}

Systemic sclerosis (SSc; scleroderma) is a systemic autoimmune disease characterised by diverse skin and internal organ involvement. The underlying pathology consists of fibrosis caused by fibroblast dysfunction and small vessel vasculopathy. It is much rarer in childhood, occurring only 1 in 1 million children, and comprises approximately $3-10 \%$ of the adult incidence $[1,2]$. Only one tenth of ju- venile scleroderma (jSSc) patients exhibit disease onset before 16 years of age, with patients under the age of 10 having an equal distribution of males and females. However, beyond this age, the predominance females in the adult patient population is increasing [3]. The currently published data suggest a dominance of the diffuse subset in children [3]. Because jSSc is considered as an orphan disease, the diagnosis very often takes several months. $[4,5]$.

\footnotetext{
${ }^{1}$ 2nd Department of Paediatrics, Semmelweis University, Budapest, Hungary

${ }^{2}$ Hamburger Zentrum für Kinder-und Jugendrheumatologie, Hamburg, Germany ${ }^{3}$ Division of Rheumatology, Department of Pediatrics,

University at Alabama, Birmingham, $A L$

Corresponding Author:

Tamás Constantin,

2nd Department of Paediatrics,

Semmelweis University,

Budapest, Hungary

e-mail:tamas.constantin@gmail.com
}

Received: Aug 12, 2014

Accepted: Dec 04, 2014

Ann Paediatr Rheum 2014;3:146-157

DOI: $10.5455 / a p r .120420141451$ 
Pediatric patients have less pulmonary and gastroesophageal involvement and the CREST-syndrome is not observed in the pediatric population [3]. Scleroderma may overlap with other autoimmune syndromes (e.g., poly/dermatomyositis, SLE), particularly in childhood [6]. Pediatric patients experience better survival rates compared to adults, as the 5-year survival rate was found to be approximately $93-95 \%[7,8]$. The reasons for these improved outcomes are probably due to the lower frequency of comorbidities and less pulmonary and pulmonary arterial involvement in children [7]. Treatment options in juvenile scleroderma are very similar, frequently adapted from the adult 'scleroderma world', and are concerned with the development of the child [1]. In the present paper, we attempt to review the hallmarks of this heterogenous disease, concentrating on novelties, new results and recommendations.

\section{Diagnosis and Classification}

In 1980, the American College of Rheumatology (ACR) submitted its diagnostic tool for systemic sclerosis [9]. The diagnosis is made if patients exhibit the major criterion of bilateral skin thickening proximal to the MCP joints, or if not satisfied, meet at least two minor criteria (sclerodactily, typical fingertip lesions, pulmonary fibrosis). More recently, two subsets of scleroderma were introduced, including limited and diffuse cutaneous disaese [10]. Other subsets were proposed as well, such as early or limited disease and SSc sine scleroderma (without skin symptoms) [11,12]. Several studies revealed that the 1980 ACR criteria can miss up to $20 \%$ of the patients with early and limited cutaneous SSc [13]. However, by that time new diagnostics tools, including the discovery of autoantibodies, appeared [14].

The scleroderma working group of the Pediatric Rheumatology European Society developed a preliminary classification criteria for juvenile systemic sclerosis [15]. The major criterion is the same skin thickening/induration as defined by the ACR. Minor criteria include peripheral vascular changes (Raynaud's phenomenon, nailfold capillary abnormalities, digital tip ulcers), and gastrointestinal, cardial, renal, and respiratory changes, as well as the presence of autoantibodies (described later on). Neurologic symptoms (neuropathy and carpal tunnel syndrome) and musculoskeletal abnormalities (tendon friction rubs, myositis, arthritis) are also listed as mi- nor criteria. A child exhibiting the major and at least two minor criteria can be classified as having jSSc [15].

The ACR and the European League Against Rheumatism (EULAR) published their joint criteria for systemic sclerosis in 2013 [14], which is similar to the preliminary pediatric classification criteria, with the difference being that certain clinical presentations carry a greater weight in the diagnosis. It also affirms the diagnostic value of bilateral skin thickening mentioned above. In addition to the previous minor criteria, telangiectasias, abnormal capillaroscopy, pulmonary arterial hypertension (PAH), Raynaud's phenomenon and SSc-related antibodies are introduced. Common symptoms, such as calcinosis, flexion contractures of the fingers, friction rubs and dysphagia did not seem to improve sensitivity or specificity in adults, so they have failed to gain inclusion as criteria. It should be well emphasized that classification criteria are not equal to diagnositic criteria, so some SSc patients do not fall into the new ACR/EULAR classification, although compared to the previously mentioned ACR and LeRoy-Medsger classifications, it was found to be superior with a more than $90 \%$ sensitivity and specificity in early SSc cases [14]. According to the latest consensus, very early SSc can be defined as Raynoud's phenomenon plus positivity of scleroderma-associated antibodies or abnormal nailfold capillaroscopy, all without internal organ involvement [16]. It should be noted that these criteria are not yet validated in children.

\section{Interstitial Lung Disease}

Interstitial lung disease (ILD) is present in 70-80\% of SSc patients, with one fourth of them exhibiting definite pulmonary fibrosis [17], which is much rarer in pediatric patients. Lung disease has now become the main cause of mortality in systemic sclerosis [18]. Experts agree that tools for ILD assesment and follow-up should be implemented regularly by conducting at least 6 to 12 monthly pulmorary function tests (PFTs), including high-resolution computed tomography (HRCT) [19]. Panigada et al. use PFTs on their own to avoid unnecessary HRCTs in pediatric patients [20]. PFTs should include forced vital capacity (FVC) measurements and diffusion studies (DLCO). Goh et al. drew attention to the fact that in adults, the use of single PFTs or HRCTs in disease extent evaluation can be misleading, so to identify disease severity 
they proposed implementing a staging system by combining the two methods. Its aim is to differenciate low and high risk patients as a robust difference that could be found in disease outcome between the two groups. High risk patients are those with an HRCT extent greater than 20\% and a FVC less than $70 \%$ [19]. Bouros et al. emphasized that non-specific interstitial pneumonia is the main histological finding in SSC-ILD. After matching patient data with histological patterns, they concluded that the clinical findings of initial pulmonary function test results and deterioration rates are superior to histological findings in forecasting disease severity [21]. Routine use of bronchoalveolar lavage (BAL) is not recommended in SSc-ILD [22]. For treatment, the most recognized regimen is cyclophosphamide pulses followed by mycophenolatemofetil (MFF) or azathioprin $[23,24]$, or primary treatment with MFF. In non-responders, a rescue rituximab treatment option is available [25]. As a last resort, a bilateral lung transplant or autologous bone marrow transplant are options [2527]. Patients who underwent pulmonary transplants have similar survival rates to those with idiopathic pulmonary fibrosis. The only significant difference between the two groups was the higher prevalence of acute rejection in SSc patients [26]. The incidence of lung cancer was found to be higher in adult patients with SSc-ILD [28].

\section{Pulmonary Arterial Hypertension}

Pulmonary vasculopathy and chronic SSc lung involvment may lead to pulmonary arterial hypertension (PAH), which is present in nearly $10-15 \%$ of adult and $7-10 \%$ of pediatric scleroderma patients $[7,29,30]$. PAH has also become one of the major causes of SSc-related deaths in the last 30 years, responsible for approximately $30 \%$ of mortalities [18]. A French study demonstrated that patients without PAH have a lower mortality rate compared to $\mathrm{PAH}$ patients $(56 \%$ 3 -year mortality versus 94\%, respectively) [31]. Early diagnosis and intervention seemed to delay PAH-associated morbidity and mortality $[32,33]$. Pulmonary veno-occlusive disease (PVOD) is a new field of interest, as patients having this disorder appear to exhibit poor survival. PVOD is characterised by the radiological triad of lymph node enlargement, centrilobular ground-glass opacities and septal lines [34]. The gold standard diagnostic tool for PAH is right heart catheterisation
(RHC). Experts agree on the fact that only selected patients should undergo this invasive examination. In juvenile systemic sclerosis, the suggested clinical care includes the following: a multi-system baseline visit plus follow-up visits scheduled every 6 months for PFTs, NTproBNP and cardiac ultrasound according to the Juvenile Systemic Sclerosis Inception Cohort [35]. For adult patients, there are two major, novel recommendations to perform this selection. Based on the two-step DETECT-score, in the first step, any SSc patient should be screened for telangiectasias, lung function (FVC and DLCO), serum urate, anti-centromere antibody, $\mathrm{N}$-terminal probrain natriuretic peptide (NTproBNP) and right axis deviation on ECG. By giving weighted points, they recommend that high-risk patients be examined with transthoracal echocardiography (right atrium area and tricuspid regurgitant velocity should be assessed). PAH-suspected cases should then be evaluated by RHC [36]. Another expert consensus released in 2014 suggests that patients with suspicion of severe PAH (i.e., having any sign of right heart failure) should be directly referred for RHC. They suggested that in order to estimate the necessity to perform RHC in patients without right-heart failure, patients with clinically significant dyspnoea (progressive dyspnoea over the past 3 months, unexplained dyspnoea and worsening of WHO dyspnoea functional class) should be sent for transthoracal echocardiography and lung function tests (DLCO) [37]. Ambiguous RHC results augurs the likely development of PAH [38]. WHO suggests PAH screening in all SSc patients [39]. Khanna et al. proposed a baseline visit, annual screening panels and reevaluation immediately if new symptoms arise. They suggest the use of the DETECT algorithm in patients with low DLCO and long disease duration (greater than 3 years) [40]. Regarding treatment, the endothelin- 1 antagonist, bosentan, should be considered in adults as a first line of treatment according to 2009 EULAR recommendations. Positive pediatric results were also found with its use $[41,42]$. The selective ETA endothelin receptor antagonist, sitexantan, can be used as an alternative if bosentan turns out to be ineffective [43]. Oral sildenafil may also be used as an option if bosentan cannot be administered [41]. Continuous intravenous eporostenol (a prostaglandin analogue) is the treatment of choice in severe, therapy-resistant PAH [41]. In 
severe patients a combination therapy of the above mentioned is suggested.

\section{Heart Involvement}

Myocardial fibrosis in scleroderma may result in conduction defects, arrythmias, sudden cardiac death and also congestive heart failure $[44,45]$. It should be emphasized that cardiac involvement (cardiac failure or arrythmias) can be a significant cause of death in jSSc, based on data collected from international patient databases $[7,46]$. In adults, because of the well-known problem of PAH, the left heart involvement was nearly neglected, but may still occur [47]. Regularly performed echocardiography and ECG are the tools for routine screening and some centers also include 24-hour Holter monitoring. A heart MRI can also be informative for determining the severity of myocardial fibrosis [48]. The use of an implantable cardioverter defibrillator (ICD) is recommended for the prevention of sudden cardiac death in cases of malignant arrythmias in high-risk patients [44].

\section{Renal Crisis}

Scleroderma renal crisis (SRC) used to be the major cause of mortality before the introduction of ACE-inhibitors [18]. They offer greater than four-fold 1-year survival compared to non-treated patients and result in notably decreased SRC-related mortality [49]. However, no controlled clinical trial has yet been conducted [41]. Individual risk factors for developing renal crises include new anaemia, new cardiac events, diffuse skin thickening, rapidly progressive skin thickening (a greater than 40 units of skin score increase per year), an SSc disease duration of more than 4 years, anti-RNA polymerase III antibody positivity and most importantly steroid use [50,51]. In conclusion, SSc, and steroid-recieving patients in particular, should be regularly monitored for renal function and blood pressure and if needed, treated with ACE-inhibitors according to the EULAR consensus [41]. Actual SSc kidney disease is a rarity in pediatric patients, including findings of serum anti-RNA polymerase III positivity [6].

\section{Gastrointestinal Involvement}

Gastrointestinal (GI) tract involvement is one of the most common internal organ manifestations in both scleroderma forms, which can be a very early symptom of the disease [52]. Notably it is seen less frequently in the pediatric population [3]. Although esophagus dysfunction is the most frequent feature, any part of the GI tract can be affected [53]. Scleroderma-related gut complications include problems associated with bowel dismotility (disphagia, intestinal pseudoobstruction, rectal prolapse, obstipation, etc.) and its consequences (e.g., malabsorption and weight loss, small bowel bacterial overgrowth syndrome, gastroesophageal reflux disease). The underlying pathological findings are fibrosis in the bowel wall, leading to muscle atrophy and nerve damage, but vasculopathy seems to play an important role as well [54]. Gastric antral vascular ectasia (GAVE), also known as "watermelon-stomach," is a rare form of GI vasculopathy in SSc that is associated with the formation of anti-RNA-polymerase III antibodies [55,56]. GAVE may cause severe bleeding and anaemia, requiring blood transfusions [56]. Radic et al. found that H. pylori infection may be associated with SSc severity [57]. A higher prevalence of Barret's esophagus was found in SSc, which seems to worsen the risk for developing neoplastic disease [58]. Routine diagnostics should include identifying specific symptoms in the patient's history, abdominal ultrasound, upper and lower GI endocopy, an $\mathrm{H} 2$ breath test and even fecal calprotectin [59]. Esophageal dilatation, as seen with non-invasive HRCT, can function as a good predictor for esophagus dismotility and is superior to scintigraphy [60]. According to EULAR therapeutical recommendations, protonpump inhibitors (PPI) should be given for the prevention of gastic complications (GERD, ulcers, GAVE). Dismotilityrelated symptoms may be relieved by prokinetic drugs (e.g., cisapride, mosapride, metoclopramide) [41]. For bacterial overgrowth problems treatment with rotated antibiotics may be useful [41]. H. pylori eradication seems to be beneficial if infection is proven [57]. In the absence of RCTs, these recommendations are based largely on expert opinion, and not on strong evidence [41]. For GAVE, several local endoscopic therapy options (argon plasma coagulation, laser photocoagulation, endoscopic band ligation, hot biopsy forceps and monopolar electrocoagulation so as injection of 5\% polidocanol) are available, so surgery (gastrectomy, antrectomy) is very seldomly needed [55].

For children, we have the same therapeutic options as in adults, but until now, no 


\section{Skin Involvement and Digital Vasculopthy}

Skin involvement and digital vasculopathy (Raynaud's phenomenon, digital ulcerations) are universal features of scleroderma. They are represented in each classification criteria for both SSc and jSSc. Although bilateral skin thickening proximal to the MCP joints is in and of itself diagnostic for scleroderma, any part of the skin can be effected. Rodnan introduced a scoring system to measure disease activity by palpating skin thickness in 17 anatomical regions. Its modified version is in widespead use for assessment, follow-up and treatment monitoring, however, it has a high interobserver variability and has not been validated for pediatric use $[16,61,62]$. In a study with "healthy children" the problems and suggestions for adapting were suggested [61]. By using a durometer this variability can be reduced and its use was comparable to mRSS and was even found to be reliable for disease activity monitoring $[63,64]$. In certain anatomic areas, however, where bony structures are found directly beneath the surface, the durometer cannot be used and in the adult 'SSc world', it is still not used on a regular basis.

Raynoud's phenomenon (RP) associated with abnormal nailfold capillaroscopy and the presence of SSc autoantibodies are hallmarks for early disease as mentioned above. Sulli et al. described the typical abnormalities found during capillaroscopy in adults, including enlarged capillaries, giant capillary loops, microhaemorrhages, loss of capillaries, disorganisation of the capillary array and capillary ramifications. It is emphasized that these findings have not yet been adapted to children, as several studies indicate that normal patterns are different in children, which evolve during maturation $[65,66]$. Therefore, standardized age-specific normal values are weighted to enhance the clinical value of capillaroscopy findings in jSSc $[62,67,68]$. Several new promising techniques have been described in the literature, such as ultrasound-based methods, laser Doppler, and optical computed tomography [62], but have yet to be validated.

Previously published data suggest that baseline skin score and the improvement rate was associated with mortality, although Shand et al. assume a more complex relationship between skin scores and visceral manifestations [69-72]. Agents used for ILD treatment (cyclophosphamide, azathioprine,
MMF) have a reported beneficial effect on skin scores, as well as methotrexate. Prevention of RP can be established by using nifedipine per os and in severe cases, intravenous iloprost is also available [41]. Bosentan had a positive effect on skin ulcers and is recommended when other therapies are ineffective $[41,73]$.

\section{Measuring Disease Activity}

It is critical that all patients are subjected to a full disease activity evaluation [74]. The European Scleroderma Study Group, representing international efforts, developed a preliminary activity index for adult patients [75-78]. Czirják et al. validated the index and according to their results, the validity of the EScSG activity index was found to be good, although lung-related disease activity may have not been sufficiently represented [78].

La Torre et al. released a pediatric disease severity score (J4S) in 2012, which is a pediatric adaption of the adult Medsger severity score $[79,80]$. This score, which can be applied to basic patient assessment, as well as follow-up, incorporates all internal organ dysfunctions and skin involvement [81]. It mainly reflects the accumulated damage caused by the disease and not so much as its activity.

In the framework of the juvenile scleroderma working group of the Paediatric Rheumatology European Society (PRES JSWG), we started to develop an activity index for jSSc. We established a system with proposed items for assessing the activity of jSSc and constructed a survey using (C) SurveyMonkey in which all participants of the paediatric rheumatology email board, the members of the PRES juvenile scleroderma working group and the active participants of the juvenile scleroderma inception cohort project were invited to participate. The web-based survey is now closed and results will be published soon.

\section{Biomarkers}

Classic humoral antinuclear antibodies (ANA) are almost exclusively (more than 90\%) positive in all SSc patients according to a recently published paper based on an international register of patient data [3]. Anti-topoisomerase-1 (a.k.a scl-70) may predict ILD or renal crisis [82]. Anti-RNA-polymerase I and III antibodies are associated with renal disease, as mentioned above [50]. Anti-centromere antibodies (ACA) 
may indicate localised disease and PAH [83]. Antinucleolar antibodies (fibrillarin, Th/To) may be present as well, predicting severe disease or PAH [84]. Any antinucleolar antibody, but primarily anti-PM-SCL and anti-U1RNP, can indicate a sign of myositis overlap syndrome $[84,85]$. These myositisrelated antibodies are significantly more common in childhood, such as in overlap syndromes. In contrast, ACA and anti-RNA-polymerase III antibodies were less frequently found compared to adult patients [6]. No difference was found between the presence of anti-scl-70 antibodies [3]. All these markers signify risks for certain organ involvement but do not fluctuate according to the level of the activity of the disease. The above mentioned pro-BNP is an accepted marker of myocardial stress in PAH monitoring [86], which is supported by pediatric studies [87-89]. Several novel biomarkers of the disease have recently been reported, with most of them relating to fibrosis pathogenesis. In a juvenile SSc patient group, Vesely et al., examining the role of a pneumocyte-derived glycoprotein (KL-6), found normal serum levels in healthy controls and non-ILD patients but high levels in ILD patients [90]. TGFbeta-1 is known for its key role in scleroderma pathogenesis [91]. Lee et al. found an association between TGF-beta-1 and chinitase-1, a substance produced in the lung, which they propose to be a new marker appropriate for monitoring ILD severity [92]. Celeste et. al. found a correlation between serum carbohydrate antigen 15.3 levels and HRCT disease severity in scleroderma [93]. Using a proteomic-wide analysis, van Born's research group identified a Toll-like receptor agonist, S100A8/A9, and plasmacytoid dendritic cell-derived CXCL4 as novel ILD biomarkers [94,95]. High serum lysyl oxidase levels in SSc patients seem to correlate specifically with skin fibrosis [96].

\section{Vitamin D Levels}

Vitamin D plays a significant role in the modulation of the immune system, exerting effects on innate immune cells, antigen presenting cells, macrophages, and $\mathrm{T}$ and $\mathrm{B}$ lymphocytes [97]. Briefly, vitamin D shifts the immune system towards a 'more tolerogenic' status [98]. Low levels of vitamin D are also present in the healthy population; therefore, it is difficult to evaluate the clinical significance of the high prevalence of vitamin $\mathrm{D}$ deficiency in patients with autoimmune diseases, which has been confirmed by several cross-sectional studies. Very low levels of vitamin $\mathrm{D}(<10 \mathrm{ng} / \mathrm{mL})$ are associated with certain symptoms and correlate with disease activity in SLE [99-101]. Several factors can influence the level of vitamin D in patients with scleroderma, as skin fibrosis can be altered with sun exposure and gut involvement can lead to malabsorption. Accordingly, vitamin D deficiency has been documented in many cross-sectional studies [102-104]. Some studies demonstrated that low vitamin D levels inversely correlate with disease activity $[102,104,105]$. Based on these observations it is assumed that vitamin D supplementation might modify disease course, but to this date there is no prospective randomized study available to prove this hypothesis. Since we know that patients with scleroderma are at risk for osteoporosis and osteoporosis-related fractures, regular screening of vitamin D levels (and supplementation of vitamin D if indicated) is advocated [106].

\section{Biologics in SSc Treatment}

The use of biological therapies is a new, active field in SSc research. Regarding most drugs, no extensive RCTs have been conducted yet; however, a number of case series are currently available. Present biologics have not provided outstanding results and are therefore not presently in routine use. Classic TNF-alpha blockers seem to improve arthritis in SSc without significantly altering mRSS or causing serious adverse events $[107,108]$. In vitro results, however, support the theory that they may worsen fibrosis through the promotion of TGF-beta secretion [109]. The IL-6 blocker, tocilizumab, also showed positive effects on joint disease, myopathy and skin involvement $[110,111]$. The role of rituximab in ILD is mentioned above, but further studies are in progress to determine whether it has other beneficial effects. B-cell targeted therapies are emerging [112-114]. Interferon type 1, which may also play a role in SSc pathogenesis, might be targeted later on [115]. A number of novel biologics in development are currently undergoing clinical trials (long-acting anti-IL-1 therapy, belimumab, abatacept, anti-IL-17, etc.). The literature is also lacking pediatric studies and case reports in this field.

Competing interests: The authors declared no competing interest.

Funding: None. 
Provenance and peer review: Not commissioned; externally peer reviewed.

\section{References}

1. Denton CP, Derrett-Smith EC. Juvenile-onset systemic sclerosis: children are not small adults. Rheumatology (Oxford). 2009; 48:96-7.

2. Herrick AL, Ennis H, Bhushan M, Silman AJ, Baildam EM. Incidence of childhood linear scleroderma and systemic sclerosis in the UK and Ireland. Arthritis Care Res (Hoboken). 2010; 62:213-8.

3. Foeldvari I, Tyndall A, Zulian F, Müller-Ladner U, Czirjak L, Denton C, et al. Juvenile and young adult-onset systemic sclerosis share the same organ involvement in adulthood: data from the EUSTAR database. Rheumatology (Oxford). 2012; 51:1832-7.

4. Weibel L, Laguda B, Atherton D, Harper JI. Misdiagnosis and delay in referral of children with localized scleroderma. BrJ Dermatol. 2011; 165:1308-13.

5. Hawley DP, Baildam EM, Amin TS, Cruikshank MK, Davidson JE, Dixon J, et al. Access to care for children and young people diagnosed with localized scleroderma or juvenile SSc in the UK. Rheumatology (Oxford). 2012;51:1235-9.

6. Scalapino K, Arkachaisri T, Lucas M, Fertig N, Helfrich DJ, Londino AV Jr, et al. Childhood onset systemic sclerosis: classification, clinical and serologic features, and survival in comparison with adult onset disease. J Rheumatol. 2006; 33:1004-13.

7. Martini G, Foeldvari I, Russo R, Cuttica R, Eberhard A, Ravelli A, et al. Systemic sclerosis in childhood: clinical and immunologic features of 153 patients in an international database. Arthritis Rheum. 2006; 54:3971-8.

8. Foeldvari I, Zhavania M, Birdi N, Cuttica RJ, de Oliveira $\mathrm{SH}$, Dent PB, et al. Favourable outcome in 135 children with juvenile systemic sclerosis: results of a multi-national survey. Rheumatology (Oxford). 2000; 39:556-9.

9. Preliminary criteria for the classification of systemic sclerosis(scleroderma). Subcommittee for scleroderma criteria of the American Rheumatism Association Diagnostic and Therapeutic Criteria Committee. Arthritis Rheum. 1980; 23:581-90.
10. LeRoy EC, Black C, Fleischmajer R, Jablonska S, Krieg T, Medsger TA Jr, et al Scleroderma (systemic sclerosis): classification, subsets and pathogenesis. J Rheumatol. 1988; 15:202-5.

11. LeRoy EC, Medsger TA Jr. Criteria for the classification of early systemic sclerosis. J Rheumatol. 2001; 28:1573-6.

12. Molina JF, Anaya JM, Cabrera GE, Hoffman E, Espinoza LR. Systemic sclerosis sine scleroderma: an unusual presentation in scleroderma renal crisis. J Rheumatol. 1995; 22:557-60

13. Walker JG, Pope J, Baron M, Leclercq S, Hudson M, Taillefer $\mathrm{S}$, et al The development of systemic sclerosis classification criteria. Clin Rheumatol. 2007; 26:1401-9.

14. van den Hoogen F, Khanna D, Fransen J, Johnson SR, Baron M, Tyndall A, et al . 2013 classification criteria for systemic sclerosis: an American College of Rheumatology/European League against Rheumatism collaborative initiative. Arthritis Rheum. 2013; 65:2737-47.

15. Zulian F, Woo P, Athreya BH, Laxer RM, Medsger TA Jr, Lehman TJ, et al. The Pediatric Rheumatology European Society/American College of Rheumatology/European League against Rheumatism provisional classification criteria for juvenile systemic sclerosis. Arthritis Rheum. 2007; 57:203-12.

16. Valentini G, Marcoccia A, Cuomo G, Iudici M, Vettori S. The concept of early systemic sclerosis following 2013 $A C R \backslash E U L A R$ criteria for the classification of systemic sclerosis. Curr Rheumatol Rev. 2014; 10:38-44.

17. Steen VD, Lanz JKJr, Conte C, Owens GR, Medsger TA Jr. Therapy for severe interstitial lung disease in systemic sclerosis. A retrospective study. Arthritis Rheum. 1994; 37:1290-6.

18. Steen VD, Medsger TA. Changes in causes of death in systemic sclerosis, 1972-2002. Ann Rheum Dis. 2007; 66:940-4.

19. Goh NS, Desai SR, Veeraraghavan S, Hansell DM, Copley SJ, Maher TM, et al Interstitial lung disease in systemic sclerosis: a simple staging system. Am J Respir Crit Care Med. 2008; 177:1248-54.

20. Panigada S, Ravelli A, Silvestri M, Granata C, MagniManzoni S, Cerveri I, et al.. HRCT and pulmonary func- 
tion tests in monitoring of lung involvement in juvenile systemic sclerosis. Pediatr Pulmonol. 2009; 44:1226-34

21. Bouros D, Wells AU, Nicholson AG, Colby TV, Polychronopoulos V, Pantelidis P, et al. Histopathologic subsets of fibrosing alveolitis in patients with systemic sclerosis and their relationship to outcome. Am J Respir Crit Care Med. 2002; 165:1581-6

22. Goh NS, Veeraraghavan S, Desai SR, Cramer D, Hansell DM, Denton CP, et al. Bronchoalveolar lavage cellular profiles in patients with systemic sclerosis-associated interstitial lung disease are not predictive of disease progression. Arthritis Rheum. 2007; 56:2005-12.

23. Au K, Khanna D, Clements PJ, Furst DE, Tashkin DP. Current concepts in disease-modifying therapy for systemic sclerosis-associated interstitial lung disease: lessons from clinical trials. Curr Rheumatol Rep. 2009; 11:111-9.

24. Cappelli S, Guiducci S, Bellando Randone S, Matucci Cerinic $\mathrm{M}$. Immunosuppression for interstitial lung disease in systemic sclerosis. Eur Respir Rev. 2013; 22:236-43.

25. Keir GJ, Maher TM, Hansell DM, Denton CP, Ong VH, Singh $S$, et al. Severe interstitial lung disease in connective tissue disease: rituximab as rescue therapy. Eur Respir J. 2012; 40:641-8.

26. Saggar R, Khanna D, Furst DE, Belperio JA, Park GS, Weigt $S S$, et al. Systemic sclerosis and bilateral lung transplantation: a single centre experience. Eur Respir J. 2010; 36:893-900.

27. Khanna D, Denton CP. Evidence-based management of rapidly progressing systemic sclerosis. Best Pract Res Clin Rheumatol. 2010; 24:387-400.

28. Colaci M, Giuggioli D, Sebastiani M, Manfredi A, Vacchi C, Spagnolo P, et al. Lung cancer in scleroderma: results from an Italian rheumatologic center and review of the literature. Autoimmun Rev. 2013; 12:374-9.

29. Launay D, Sitbon O, Le Pavec J, Savale L, Tchérakian C, Yaïci A, et al. Long-term outcome of systemic sclerosisassociated pulmonary arterial hypertension treated with bosentan as first-line monotherapy followed or not by the addition of prostanoids or sildenafil. Rheumatology (Oxford). 2010; 49:490-500.

30. Avouac J, Airò P, Meune C, Beretta L, Dieude P, Cara- maschi P, et al. Prevalence of pulmonary hypertension in systemic sclerosis in European Caucasians and metaanalysis of 5 studies.J Rheumatol. 2010; 37:2290-8.

31. Hachulla E, Carpentier P, Gressin V, Diot E, Allanore Y, Sibilia J, et al. Risk factors for death and the 3-year survival of patients with systemic sclerosis: the French ItinérAIRSclérodermie study. Rheumatology (Oxford). 2009; 48:304-8.

32. Galiè N, Rubin Lj, Hoeper M, Jansa P, Al-Hiti H, Meyer $\mathrm{G}$, et al. Treatment of patients with mildly symptomatic pulmonary arterial hypertension with bosentan (EARLY study): a double-blind, randomised controlled trial. Lancet. 2008; 371:2093-100.

33. Humbert M, Yaici A, de Groote P, Montani D, Sitbon O, Launay D, et al. Screening for pulmonary arterial hypertension in patients with systemic sclerosis: clinical characteristics at diagnosis and long-term survival. Arthritis Rheum. 2011; 63:3522-30.

34. Günther S, Jaïs X, Maitre S, Bérezné A, Dorfmüller P, Seferian A, et al. Computed tomography findings of pulmonary venoocclusive disease in scleroderma patients presenting with precapillary pulmonary hypertension. Arthritis Rheum 2012; 64:2995-3005.

35.

36. Coghlan JG, Denton CP, Grünig E, Bonderman D, Distler O, Khanna D, et al. Evidence-based detection of pulmonary arterial hypertension in systemic sclerosis: the DETECT study. Ann Rheum Dis. 2014; 73:1340-9.

37. Avouac J, Huscher D, Furst DE, Opitz CF, Distler O, Allanore $\mathrm{Y}$, et al. Expert consensus for performing right heart catheterisation for suspected pulmonary arterial hypertension in systemic sclerosis: a Delphi consensus study with cluster analysis. Ann Rheum Dis. 2014; 73:191-7.

38. Condliffe R, Kiely DG, Peacock AJ, Corris PA, Gibbs JS, Vrapi F, et al. Connective tissue disease-associated pulmonary arterial hypertension in the modern treatment era. Am J Respir Crit Care Med. 2009; 179:151-7.

39. Proceedings of the 4th World Symposium on Pulmonary Hypertension, February 2008, Dana Point, California, USA.J Am Coll Cardiol. 2009; 54(1 Suppl):S1-117.

40. Khanna D, Gladue H, Channick R, Chung L, Distler 
$\mathrm{O}$, Furst DE, et al. Recommendations for screening and detection of connective tissue disease-associated pulmonary arterial hypertension. Arthritis Rheum. 2013; 65:3194-201.

41. Kowal-Bielecka O, Landewé R, Avouac J, Chwiesko S, Miniati I, Czirjak L, et al. EULAR recommendations for the treatment of systemic sclerosis: a report from the EULAR Scleroderma Trials and Research group (EUSTAR). Ann Rheum Dis. 2009; 68:620-8.

42. Shimizu M, Hashida Y, Ueno K, Yokoyama T, Nakayama Y, Saito T, et al. Successful treatment with bosentan for pulmonary hypertension and reduced peripheral circulation in juvenile systemic sclerosis.Pediatr Cardiol. 2011; 32:1040-2.

43. Benza RL, Mehta S, Keogh A, Lawrence EC, Oudiz RJ, Barst RJ. Sitaxsentan treatment for patients with pulmonary arterial hypertension discontinuing bosentan. J Heart Lung Transplant. 2007; 26:63-9.

44. Bernardo P, Conforti ML, Bellando-Randone S, Pieragnoli P, Blagojevic J, Kaloudi O, et al. Implantable cardioverter defibrillator prevents sudden cardiac death in systemic sclerosis.J Rheumatol. 2011; 38:1617-21.

45. Follansbee WP, Zerbe TR, Medsger TA Jr. Cardiac and skeletal muscle disease in systemic sclerosis (scleroderma): a high risk association. Am Heart J. 1993; 125:194203.

46. Foeldvari I. Current developments in pediatric systemic sclerosis. Curr Rheumatol Rep. 2009; 11:97-102.

47. Allanore Y, Meune C, Vonk MC, Airo P, Hachulla E, Caramaschi $\mathrm{P}$, et al. Prevalence and factors associated with left ventricular dysfunction in the EULAR Scleroderma Trial and Research group (EUSTAR) database of patients with systemic sclerosis. Ann Rheum Dis. 2010; 69:218-21.

48. Tzelepis GE, Kelekis NL, Plastiras SC, Mitseas P, Economopoulos N, Kampolis C, et al. Pattern and distribution of myocardial fibrosis in systemic sclerosis: a delayed enhanced magnetic resonance imaging study. Arthritis Rheum. 2007; 56:3827-36. .

49. Steen VD, Costantino JP, Shapiro AP, Medsger TA Jr. Outcome of renal crisis in systemic sclerosis: relation to availability of angiotensin converting enzyme (ACE) inhibi- tors. Ann Intern Med. 1990; 113:352-7.

50. DeMarco PJ, Weisman MH, Seibold JR, Furst DE, Wong WK, Hurwitz EL, et al. Predictors and outcomes of scleroderma renal crisis: the high-dose versus low-dose Dpenicillamine in early diffuse systemic sclerosis trial. Arthritis Rheum. 2002; 46:2983-9.

51. Perera A, Fertig N, Lucas M, Rodriguez-Reyna TS, Hu P, Steen VD, et al. Clinical subsets, skin thickness progression rate, and serum antibody levels in systemic sclerosis patients with anti-topoisomerase I antibody. ArthritisRheum. 2007; 56:2740-6.

52. Lepri G, Guiducci S, Bellando-Randone S, Giani I, Bruni C, Blagojevic J, et al.. Evidence for oesophageal and anorectal involvement in very early systemic sclerosis (VEDOSS): report from a single VEDOSS/EUSTAR centre. Ann Rheum Dis. 2015 ; 74:124-8.

53. Lock G, Holstege A, Lang B, Schölmerich J. Gastrointestinal manifestations of progressive systemic sclerosis. Am J Gastroenterol. 1997; 92:763-71.

54. Manetti M, Neumann E, Milia AF, Tarner IH, Bechi P, Matucci-Cerinic M, et al. Severe fibrosis and increased expression of fibrogenic cytokines in the gastric wall of systemic sclerosis patients. Arthritis Rheum. 2007; 56:3442-7.

55. Johnson J, Derk CT. Gastric antral vascular ectasia in systemic sclerosis. Int J Rheumatol. 2011; 2011:305238.

56. Ghrénassia E, Avouac J, Khanna D, Derk CT, Distler O, Suliman YA, et al. Prevalence, correlates and outcomes of gastric antral vascular ectasia in systemic sclerosis: a EUSTAR case-control study. J Rheumatol. 2014; 41:99-105.

57. Radić M, Kaliterna DM, Bonacin D, Vergles JM, Radić J, Fabijanić D, et al. sclerosis? Rheumatol Int. 2013; 33:2943-8.

58. WipffJ, Coriat R, Masciocchi M, Caramaschi P, Derk CT, Hachulla E, et al. Outcomes of Barrett's oesophagus related to systemic sclerosis: a 3-year EULAR Scleroderma Trials and Research prospective follow-up study. Rheumatology (Oxford). 2011; 50:1440-4.-

59. Andréasson K, Scheja A, Saxne T, Ohlsson B, Hesselstrand R. Faecal calprotectin: a biomarker of gastrointestinal disease in systemic sclerosis. J Intern Med. 2011; 
270:50-7.

60. Pitrez EH, Bredemeier M, Xavier RM, Capobianco KG, Restelli VG, Vieira MV, et al.Oesophageal dysmotility in systemic sclerosis: comparison of HRCT and scintigraphy. Br J Radiol. 2006 ;79:719-24. .

61. Foeldvari I, Wierk A. Healthy children have a significantly increased skin score assessed with the modified Rodnan skin score. Rheumatology (Oxford). 2006; 45:76-8.

62. Foeldvari, I., New developments in juvenile systemic and localized scleroderma. Rheum Dis Clin North Am, 2013; 39:905-20.

63. Falanga V, Bucalo B. Use of a durometer to assess skin hardness. J Am Acad Dermatol. 1993; 29:47-51.

64. Aghassi D, Monoson T, Braverman I. Reproducible measurements to quantify cutaneous involvement in scleroderma. Arch Dermatol. 1995; 131:1160-6.

65. Sulli A, Pizzorni C, Smith V, Zampogna G, Ravera F, Cutolo M. Timing of transition between capillaroscopic patterns in systemic sclerosis. Arthritis Rheum. 2012; 64:821-5..

66. Cutolo M, Sulli A, Smith V. Assessing microvascular changes in systemic sclerosis diagnosis and management. Nat Rev Rheumatol. 2010; 6:578-87.

67. Terreri MT, Andrade LE, Puccinelli ML, Hilário MO, Goldenberg J. Nail fold capillaroscopy: normal findings in children and adolescents. Semin Arthritis Rheum. 1999; 29:36-42.

68. Herrick AL, Moore T, Hollis S, Jayson MI. The influence of age on nailfold capillary dimensions in childhood. J Rheumatol. 2000; 27:797-800.

69. Valentini G, Marcoccia A, Cuomo G, Vettori S, Iudici M, Bondanini F, et al. Early systemic sclerosis: marker autoantibodies and videocapillaroscopy patterns are each associated with distinct clinical, functional and cellular activation markers. Arthritis Res Ther. 2013; 15:R63.

70. Clements PJ, Hurwitz EL, Wong WK, Seibold JR, Mayes M, White B, et al. Skin thickness score as a predictor and correlate of outcome in systemic sclerosis: high-dose versus low-dose penicillamine trial. Arthritis Rheum. 2000; 43:2445-54.

71. Steen VD, Medsger TA Jr. Improvement in skin thicken- ing in systemic sclerosis associated with improved survival. Arthritis Rheum. 2001; 44:2828-35.

72. Shand L, Lunt M, Nihtyanova S, Hoseini M, Silman A, Black CM, et al. Relationship between change in skin score and disease outcome in diffuse cutaneous systemic sclerosis: application of a latent linear trajectory model. Arthritis Rheum. 2007; 56:2422-31.

73. Tingey T, Shu J, Smuczek J, Pope J. Meta-analysis of healing and prevention of digital ulcers in systemic sclerosis. Arthritis Care Res (Hoboken). 2013; 65:1460-71.

74. Czirják L, Matucci-Cerinic M. Beyond Raynaud’s phenomenon hides very early systemic sclerosis: the assessment of organ involvement is always mandatory. Rheumatology (Oxford). 2011; 50:250-1.

75. Della Rossa A, Valentini G, Bombardieri S, Bencivelli W, Silman AJ, D’Angelo S, et al. European multicentre study to define disease activity criteria for systemic sclerosis. I. Clinical and epidemiological features of 290 patients from 19 centres. Ann Rheum Dis. 2001; 60:585-91.

76. Valentini G, Della Rossa A, Bombardieri S, Bencivelli W, Silman AJ, D’Angelo S, et al. European multicentre study to define disease activity criteria for systemic sclerosis. II. Identification of disease activity variables and development of preliminary activity indexes. Ann Rheum Dis. 2001; 60:592-8

77. Valentini G, Bencivelli W, Bombardieri S, D’Angelo S, Della Rossa A, Silman AJ, et al. European Scleroderma Study Group to define disease activity criteria for systemic sclerosis. III. Assessment of the construct validity of the preliminary activity criteria. Ann Rheum Dis. 2003; 62:901-3.

78. MinierT,NagyZ, BálintZ, FarkasH, RadicsJ,Kumánovics $G$, et al. Construct validity evaluation of the European Scleroderma Study Group activity index, and investigation of possible new disease activity markers in systemic sclerosis. Rheumatology (Oxford). 2010; 49:1133-45.

79. Medsger TA Jr, Silman AJ, Steen VD, Black CM, Akesson A, Bacon PA, et al. A disease severity scale for systemic sclerosis: development and testing. J Rheumatol. 1999; 26:2159-67.

80. Medsger TA Jr, Bombardieri S, Czirjak L, Scorza R, Della 
Rossa A, Bencivelli W. Assessment of disease severity and prognosis. Clin Exp Rheumatol. 2003; 21:42-6.

81. La Torre F, Martini G, Russo R, Katsicas MM, Corona F, Calcagno G, et al. A preliminary disease severity score for juvenile systemic sclerosis. Arthritis Rheum. 2012; 64:4143-50.

82. Schorn R, Gaspert A, Cohen CD. [Anti-RNA polymerase III antibodies in scleroderma renal crisis]. Dtsch Med Wochenschr. 2010; 135:1118-21

83. Reveille JD, Solomon DH; American College of Rheumatology Ad Hoc Committee of Immunologic Testing Guidelines. Evidence-based guidelines for the use of immunologic tests: anticentromere, Scl-70, and nucleolar antibodies. Arthritis Rheum. 2003; 49:399-412.

84. Graf SW, Hakendorf P, Lester S, Patterson K, Walker JG, Smith MD, et al. South Australian Scleroderma Register: autoantibodies as predictive biomarkers of phenotype and outcome. Int J Rheum Dis. 2012; 15:102-9.

85. Nihtyanova SI, Denton CP. Autoantibodies as predictive tools in systemic sclerosis. Nat Rev Rheumatol. 2010; 6:112-6.

86. Hakkar V, Stevens W, Prior D, Youssef P, Liew D, Gabbay $\mathrm{E}$, et al. The inclusion of $\mathrm{N}$-terminal pro-brain natriuretic peptide in a sensitive screening strategy for systemic sclerosis-related pulmonary arterial hypertension: a cohort study. Arthritis Res Ther. 2013;15(6):R193.

87. Borowiec A, Dabrowski R, Wozniak J, Jasek S, Chwyczko T, Kowalik I, et al. Cardiovascular assessment of asymptomatic patients with juvenile-onset localized and systemic scleroderma: 10 years prospective observation. Scand J Rheumatol. 2012; 41:33-8

88. van Loon RL, Roofthooft MT, Delhaas T, van OschGevers M, ten Harkel AD, Strengers JL, et al Outcome of pediatric patients with pulmonary arterial hypertension in the era of new medical therapies. Am J Cardiol. 2010; 106:117-24.

89. Lammers AE, Hislop AA, Haworth SG. Prognostic value of $\mathrm{B}$-type natriuretic peptide in children with pulmonary hypertension. Int J Cardiol. 2009; 135:21-6.

90. Veselý R, Vargová V, Ravelli A, Massa M, Oleksák E, D'Alterio R, et al Serum level of KL-6 as a marker of in- terstitial lung disease in patients with juvenile systemic sclerosis. J Rheumatol. 2004; 31:795-800.

91. Andrews, A.R.J.L.A.H., Tissue localization of transforming growth factor-b1 in nonspecific insterstitial pneumonities compared with usual inter- stitial pneumonitis. Chest, 2001; 120:70-71.

92. Lee CG, Herzog EL, Ahangari F, Zhou Y, Gulati M, Lee $\mathrm{CM}$, et al. Chitinase 1 is a biomarker for and therapeutic target in scleroderma-associated interstitial lung disease that augments TGF- $\beta 1$ signaling. J Immunol. 2012; 189:2635-44.

93. Celeste S, Santaniello A, Caronni M, Franchi J, Severino A, Scorza R, et al. Carbohydrate antigen 15.3 as a serum biomarker of interstitial lung disease in systemic sclerosis patients. Eur J Intern Med. 2013; 24:671-6.

94. van Bon L, Affandi AJ, Broen J, Christmann RB, Marijnissen RJ, Stawski L, et al. Proteome-wide analysis and CXCL4 as a biomarker in systemic sclerosis. N Engl J Med. 2014 Jan 30;370(5):433-43.van Bon, L., et al., Proteome-wide analysis and CXCL4 as a biomarker in systemic sclerosis. N Engl J Med, 2014; 370:433-43.

95. van Bon L, Cossu M, Loof A, Gohar F, Wittkowski H, Vonk M, et al Proteomic analysis of plasma identifies the Toll-like receptor agonists S100A8/A9 as a novel possible marker for systemic sclerosis phenotype. Ann Rheum Dis. 2014;73:1585-9.

96. Rimar D, Rosner I, Nov Y, Slobodin G, Rozenbaum M, Halasz K, et al. Brief report: lysyl oxidase is a potential biomarker of fibrosis in systemic sclerosis. Arthritis Rheumatol. 2014; 66:726-30.

97. Mora JR, Iwata M, von Andrian UH. Vitamin effects on the immune system: vitamins $\mathrm{A}$ and $\mathrm{D}$ take centre stage. Nat Rev Immunol. 2008; 8:685-98.

98. Prietl B, Treiber G, Pieber TR, Amrein K. Vitamin D and immune function. Nutrients. 2013; 5:2502-21. .

99. Mok, C.C., Vitamin D and systemic lupus erythematosus: an update. Expert Rev Clin Immunol, 2013; 9:453-63.

100.Sakthiswary R, Raymond AA. The clinical significance of vitamin $\mathrm{D}$ in systemic lupus erythematosus: a systematic review. PLoS One. 2013; 8:e55275.

101.Amital H, Szekanecz Z, Szücs G, Dankó K, Nagy E, 
Csépány T, et al. Serum concentrations of $25-\mathrm{OH}$ vitamin $\mathrm{D}$ in patients with systemic lupus erythematosus (SLE) are inversely related to disease activity: is it time to routinely supplement patients with SLE with vitamin D? Ann Rheum Dis. 2010; 69:1155-7.

102.Caramaschi P, Dalla Gassa A, Ruzzenente O, Volpe A, Ravagnani V, Tinazzi I, et al. Very low levels of vitamin D in systemic sclerosis patients. Clin Rheumatol. 2010; 29:1419-25.

103.Rios Fernández R, Fernández Roldán C, Callejas Rubio JL, Ortego Centeno N. Vitamin D deficiency in a cohort of patients with systemic scleroderma from the south of Spain. J Rheumatol. 2010; 37:1355

104.Vacca A, Cormier C, Piras M, Mathieu A, Kahan A, Allanore Y. Vitamin D deficiency and insufficiency in 2 independent cohorts of patients with systemic sclerosis. J Rheumatol. 2009; 36: 1924-9.

105.Arnson Y, Amital H, Agmon-Levin N, Alon D, SánchezCastañón M, López-Hoyos M, et al. Serum 25-OH vitamin $\mathrm{D}$ concentrations are linked with various clinical aspects in patients with systemic sclerosis: a retrospective cohort study and review of the literature. Autoimmun Rev. 2011; 10:490-4.

106. Omair MA, Pagnoux C, McDonald-Blumer H, Johnson SR. Low bone density in systemic sclerosis. A systematic review.J Rheumatol. 2013; 40:1881-90.

107.Lam GK, Hummers LK, Woods A, Wigley FM. Efficacy and safety of etanercept in the treatment of sclerodermaassociated joint disease. J Rheumatol. 2007; 34:1636-7.

108.Denton CP, Engelhart M, Tvede N, Wilson H, Khan K, Shiwen X, et al. An open-label pilot study of infliximab therapy in diffuse cutaneous systemic sclerosis. Ann
Rheum Dis. 2009; 68: 1433-9.

109.Abraham DJ, Shiwen X, Black CM, Sa S, Xu Y, Leask A. Tumor necrosis factor alpha suppresses the induction of connective tissue growth factor by transforming growth factor-beta in normal and scleroderma fibroblasts. J Biol Chem. 2000; 275:15220-5. .

110.Shima Y, Kuwahara Y, Murota H, Kitaba S, Kawai M, Hirano $\mathrm{T}$, et al. The skin of patients with systemic sclerosis softened during the treatment with anti-IL-6 receptor antibody tocilizumab. Rheumatology (Oxford). 2010; 49:2408-12.

111.Elhai M, Meunier M, Matucci-Cerinic M, Maurer B, Riemekasten G, Leturcq T, et al. Outcomes of patients with systemic sclerosis-associated polyarthritis and myopathy treated with tocilizumab or abatacept: a EUSTAR observational study. Ann Rheum Dis. 2013 ; 72:1217-20.

112.Blüml S, McKeever K, Ettinger R, Smolen J, Herbst R. Bcell targeted therapeutics in clinical development. Arthritis Res Ther. 2013; 5 Suppl 1:S4.

113.Smith V, Van Praet JT, Vandooren B, Van der Cruyssen B, Naeyaert JM, Decuman S, et al. Rituximab in diffuse cutaneous systemic sclerosis: an open-label clinical and histopathological study. Ann Rheum Dis. 2010; 69:193-7.

114.Daoussis D, Liossis SN, Tsamandas AC, Kalogeropoulou C, Paliogianni F, Sirinian C, et al. Effect of long-term treatment with rituximab on pulmonary function and skin fibrosis in patients with diffuse systemic sclerosis. Clin Exp Rheumatol. 2012; 30:17-22.

115.Liu X, Mayes MD, Tan FK, Wu M, Reveille JD, Harper $\mathrm{BE}$, et al. Correlation of interferon-inducible chemokine plasma levels with disease severity in systemic sclerosis. Arthritis Rheum. 2013; 65:226-35. 